NBER WORKING PAPER SERIES

\title{
EXPECTATIONS AND THE EFFECTS \\ OF MONETARY POLICY
}

Laurence Ball

Dean Croushore

Working Paper 5344

\author{
NATIONAL BUREAU OF ECONOMIC RESEARCH \\ 1050 Massachusetts Avenue \\ Cambridge, MA 02138 \\ November 1995
}

We are grateful for research assistance from PJ Miller, and for suggestions from Charles Evans, David Romer, Matthew Shapiro, and participants in seminars at the 1994 NBER Summer Institute, the Federal Reserve Bank of Philadelphia, the Federal Reserve System Committee on Business Analysis, and Penn State University. This paper is part of NBER's research programs in Economic Fluctuations and Monetary Economics. Any opinions expressed are those of the authors and not those of the Federal Reserve Bank of Philadelphia, the Federal Reserve System, or the National Bureau of Economic Research.

(C) 1995 by Laurence Ball and Dean Croushore. All rights reserved. Short sections of text, not to exceed two paragraphs, may be quoted without explicit permission provided that full credit, including $\odot$ notice, is given to the source. 
NBER Working Paper 5344

November 1995

\title{
EXPECTATIONS AND THE EFFECTS \\ OF MONETARY POLICY
}

\begin{abstract}
This paper examines the predictive power of shifts in monetary policy, as measured by changes in the federal funds rate, for output, inflation, and survey expectations of these variables. We find that policy shifts have larger effects on actual output than on expected output, suggesting that agents underestimate the effects of policy on aggregate demand. Our results help to explain the real effects of monetary policy, and they provide a strong rejection of the rational expectations hypothesis.
\end{abstract}

Laurence Ball

Department of Economics

Johns Hopkins University

Baltimore, MD 21218

and NBER
Dean Croushore

Research Division

Federal Reserve Bank of Philadelphia

10 Independence Mall

Philadelphia, PA 19106 


\section{INTRODUCTION}

There is a growing consensus, based on both historical analysis and econometric evidence, that monetary policy has strong effects on real output. There is not, however, any consensus about how to explain this fact. Monetary policy causes shifts in aggregate demand, but why does demand affect real output? This paper presents evidence that suggests an answer: private agents systematically underestimate the effects of policy on demand.

Our central evidence concerns the predictive power of policy shifts for real output and for expectations of output. We measure policy shifts with changes in the federal funds rate; expectations are taken from the Survey of Professional Forecasters (SPF) and the Livingston Survey. Like previous researchers, we find that increases in the funds rate reduce output at a horizon of roughly a year. A higher funds rate also causes survey respondents to expect lower output, but the effect on expected output is substantially smaller than the effect on actual output. Thus increases in the funds rate lead systematically to negative errors in output expectations. We interpret this result to mean that agents underestimate the effects of monetary policy on demand. The result helps to explain the real effects of policy, because theoretical models 
predict that unanticipated demand shifts affect output.

Our result also has implications for the broader issue of the behavior of expectations. Changes in the federal funds rate are observable to private agents, so our finding that changes in the funds rate predict expectational errors is a violation of the rational-expectations hypothesis. We contribute a strong piece of negative evidence to the debate over the empirical validity of rational expectations.

In addition to examining real output, we investigate the predictive power of the federal funds rate for inflation and for expectations of inflation, using the Michigan Survey of Consumers as well as the SPF and Livingston surveys. Once again, we reject rational expectations. Perhaps surprisingly, this result arises because an increase in the funds rate is associated with higher inflation for several quarters, which agents do not expect. We interpret the increase in inflation as arising from the shocks that caused the Fed to tighten policy. A rise in the funds rate leads to lower inflation at longer horizons, but these effects are reflected fully in expectations.

The remainder of this paper contains three sections. Section II describes our methodology and section III presents the results. In section IV, we discuss implications for the effects 
of monetary policy and for the behavior of expectations.

\section{II . METHODOLOGY}

We explore the predictive power of shifts in monetary policy for three output variables: actual output, expected output as measured by surveys, and the difference between the two. We perform a similar procedure for inflation. Here we describe the details of our approach.

\section{A. The Basic Regressions}

We measure shifts in monetary policy with changes in the federal funds rate. This is consistent with discussions of policy in the business press, which interprets increases in the funds rate as tighter monetary policy and decreases as easier policy. In addition, there is a growing consensus among academic researchers that changes in the funds rate are a good measure of policy (Bernanke and Blinder, 1992; Christiano and Eichenbaum, 1992). In all our regressions, the right-hand-side variables are lags of the change in the funds rate. ${ }^{1}$

The left-hand side variables in our regressions are

${ }^{1}$ Bernanke-Blinder and Christiano-Eichenbaum measure policy with innovations in the funds rate from a vector autoregression. We use raw changes in the funds rate for simplicity. 
constructed from data on output and inflation, and survey expectations of these variables. For both actual variables and expectations, we examine deviations from the forecasts of univariate statistical models. That is, we ask whether policy causes inflation and output to deviate from the paths that one would forecast based on their usual dynamics, and whether survey respondents expect these deviations. For univariate forecasting models, we choose simple specifications suggested by previous work. We assume that quarterly output follows a random walk with drift, where the drift term changes in 1973Q2. We assume that quarterly inflation follows an IMA $(1,1)$ process. Given these assumptions, we compute statistical forecasts using rolling regressions. ${ }^{2}$

Letting $y$ denote output, $y^{e}$ denote survey expectations of output, and $y^{f}$ denote statistical forecasts, we ask whether changes in the funds rate predict $y-y^{f}$ and whether they predict $y^{e}-y^{f}$. We also examine the difference between these two

${ }^{2}$ The assumption that inflation follows an IMA $(1,1)$ process is based on Barsky (1987) and Ball and Cecchetti (1990). The assumption that output follows a random walk with drift is based on Campbell and Mankiw (1987) and Beveridge and Nelson (1981). (Campbell and Mankiw suggest that an $A R(1)$ or $A R(2)$ for output growth may be better, but not by a lot, so we assume a random walk for parsimony.) Perron (1989) proposes a shift in the drift term in 197302, the date of the first OPEC shock. 
variables to see whether policy shifts lead systematically to expectational errors. Note that this difference is simply $y$ $y^{e}$, and thus is not affected by our choice of statistical models. For inflation, we define $\pi, \Pi^{e}$, and $\Pi^{f}$ similarly and examine the analogous combinations of variables.

\section{B. Measuring Expectations}

We perform our analysis for three surveys of expectations: the Survey of Professional Forecasters (SPF), the Livingston Survey of business economists, and the Michigan survey of Consumers. ${ }^{3}$ The SPF and Livingston surveys provide expectations of real GNP (or GDP starting in 1992); all three surveys provide expectations of inflation, defined by the GNP deflator for the SPF and the Consumer Price Index for Livingston and Michigan. In all cases, we use the mean forecasts of survey respondents.

The three surveys vary widely in the sophistication of their respondents. Keane and Runkle (1990) argue that only the SPF is reliable, because it surveys people whose incomes depend on the quality of their forecasts. The Livingston respondents are economists, but not necessarily forecasters. Clearly the

${ }^{3}$ For detailed descriptions of these surveys, see Croushore (1993) for the Survey of Professional Forecasters, Taylor (1992) for the Livingston Survey, and Noble and Fields (1982) for the Michigan Survey. 
Michigan respondents are the least sophisticated, because they are selected randomly from the U.S. population. One might expect the properties of expectations to vary widely across the surveys. It turns out, however, that the three surveys yield similar results in our empirical work.

\section{Timing}

We use quarterly data from both the SPF and the Michigan survey. We examine overlapping observations of expected and actual variables over periods of one year. For an observation dated at quarter $t$, actual inflation is inflation from $t$ to $t+4$. Our output variable is output growth from to $t+4$. Expected inflation and growth from $t$ to $t+4$ are reported by survey respondents during quarter $t$. Finally, our statistical forecasts of output and inflation are based on quarterly models estimated through $t-1$ (the last quarter for which data are available during quarter $t$ ).

The Livingston Survey provides overlapping semiannual observations. Because of the precise timing of the survey, expectations of output growth are for growth over five quarters rather than a year. Expectations of inflation cover 14 months. We adjust our measures of actual output and inflation to match this timing. 
We measure changes in the broad stance of policy with changes in the federal funds rate over periods of a year. For observation $t, F F 1$ is the difference between the average funds rate in quarter $t-1$ (the last quarter completed before expectations are formed) and the average four quarters earlier, during t-5. FF2 is the difference between the funds rates at $t-5$ and at $t-9$, and $F F 3$ is the difference between $t-9$ and $t-13$. These annual changes in the funds rate are the regressors in our equations for actual and expected inflation and output. (As described below, we also experiment with funds-rate changes over shorter periods.)

The SPF data begin in 196804 and the Michigan data in 1969Q1. The Livingston inflation data go back to the 1940s; we use observations beginning in 1958H1, the earliest period for which data on the lagged funds rate are readily available. The Livingston output data begin in 1971HI. In all of our regressions, the sample ends in 1992Q4 for the SPF and Michigan surveys and in $1992 \mathrm{H} 2$ for Livingston.

Further details of our procedures are provided in the Data Appendix to the paper. 


\section{RESULTS}

\section{A. Output}

Tables 1 and 2 report our results concerning real output for the SPF and Livingston surveys. For each survey, we regress $y$ $y^{f}, y^{e}-y^{f}$, and $y-y^{e}$ on lags of the federal-funds variables. We focus on the results with $F F 1$ as the only regressor; we also report results with both $F F 1$ and $F F 2$, but $F F 2$ is never significant. We compute standard errors using the Newey-West (1987) procedure. (OLS standard errors are inconsistent because our use of overlapping observations induces serial correlation.) For each regression, we present the significance level of the $x^{2}$ statistic for the null hypothesis that all coefficients on the FF variables are zero.

The results for the two surveys are similar. Not surprisingly, $F F 1$ has a negative and highly significant effect on $y-y^{f}$. That is, output growth falls below the level predicted by a univariate forecast if the federal funds rate rose in the previous year. In the SPF results, the FFI coefficient implies that a one-percentage-point rise in the funds rate reduces output by about 0.8 percentage points.

In both surveys, $F F 1$ also has a negative effect on $y^{e}-y^{f}$ : a rise in the funds rate in the previous year leads survey 
respondents to expect lower output. However, the fall in expected output from a one-point rise in the funds rate is only about 0.4 percent -- about half of the effect on actual output. The effect of FF1 on $y-y^{e}$, the expectational error, is the difference between the effects on actual and expected output. Thus a one-point rise in the funds rate reduces $y-y^{e}$ by approximately $0.8-0.4=0.4$ percent. This effect is statistically significant $(t=3.0$ for $\mathrm{SPF}$ and $t=2.5$ for Livingston).$^{4}$

For the SPF and Livingston data, Figure 1 presents scatterplots of $y-y^{e}$ against FF1. The figure confirms the negative relationship between these variables and shows that the relationship does not depend on a few outliers.

The significant effect of FFI on $y-y^{e}$ is a violation of rational expectations, because survey respondents know $F F 1$ when they form their expectations. Rationality is rejected because respondents systematically underestimate the effects of changes in the federal funds rate on output.

${ }^{4}$ Note that, in Table 1 , each coefficient in the equation for $y$ - $y^{e}$ is exactly the difference of the corresponding coefficients in the equations for $y-y^{f}$ and $y^{e}-y^{f}$. This fact follows algebraically from the properties of oLs. 


\section{B. Inflation}

Tables 3, 4, and 5 present results for inflation data using the SPF, Livingston, and Michigan surveys. We regress $\Pi$ $\Pi^{f}, \Pi^{e}-\Pi^{f}$, and $\Pi-\Pi^{e}$ on various combinations of $F F 1, F F 2$, and FF3. We have checked that longer lags are not significant. Once again, the results are consistent across the different surveys. In all cases, rationality is rejected at the 5 percent level when only FFI is included in the equation, because this variable has predictive power for $\Pi-\Pi^{e}$. Rationality is sometimes rejected when additional lags are included, but the results are weaker because these variables do not predict $\Pi-\Pi^{e}$. Perhaps surprisingly, the effects of FFI on $\pi-\Pi^{e}$ are positive. That is, a rise in the funds rate leads to unexpectedly high inflation in the following year.

These results are easier to interpret with a variation on our basic regressions. Table 6 presents results using changes in the federal funds rate over past guarters rather than past years. We regress $\Pi-\Pi^{f}, \Pi^{e}-\Pi^{f}$, and $\Pi-\Pi^{e}$ on 12 lags of the quarterly change in the funds rate. These regressions relax the restriction, implicit in our basic specification, that rate changes in different quarters of the same year have the same effects. We report results for the SPF (results for the other 
surveys are similar).

In the equation for actual inflation, $\Pi-\Pi^{f}$, the first three lags of the quarterly change in the funds rate have positive coefficients, and lags four through 12 have negative coefficients. The negative coefficients confirm the conventional wisdom that tighter policy eventually reduces inflation. The interpretation of the positive coefficients is less obvious, but a natural candidate involves causality from inflation to policy. When the Fed raises the funds rate, it is presumably responding to inflationary pressures, such as supply shocks or low unemployment (below the natural rate or NAIRU). These pressures lead to higher inflation for several quarters following the rate increase, before the disinflationary effects of the policy take hold. ${ }^{5}$

In Table 6 , the major difference between the behavior of actual and expected inflation is the effects of the first three lags of the funds rate. In contrast to the positive effects on $\Pi$ - $\Pi^{f}$, the effects on $\Pi^{e}-\Pi^{f}$ are close to zero or negative. That is, when the funds rate rises, survey respondents fail to

${ }^{5}$ Our result that a monetary tightening leads initially to higher inflation is similar to the "price puzzle" that arises in vector autoregressions (Christiano and Eichenbaum, 1992). 
anticipate the short-run increase in inflation that usually occurs. At longer lags, the funds rate has negative effects on expected inflation that are close to its effects on actual inflation. The results for the first three lags explain why, when funds-rate changes are averaged over a year, the first annual lag has a positive effect on $\pi-\Pi^{e} .^{6}$

\section{DISCUSSION AND CONCLUSIONS}

We conclude by interpreting our results. Part A discusses the implications for the effects of monetary policy. Part B considers broader issues concerning the behavior of expectations.

\section{A. The Real Effects of Monetary Policy}

The behavior of expectations is crucial to the effects of monetary policy on real output. Recent research suggests that these effects are difficult to explain under the assumption of rational expectations, even using models with frictions in wageand price-setting. In particular, models of staggered price adjustment such as Taylor (1979) do not predict the high degree

6 One cannot see all the effects of policy using the results with annual funds-rate changes. In particular, the positive effect of tight policy on $\Pi-\Pi^{\mathrm{f}}$ is obscured because positive effects in the first three quarters are averaged with a negative effect in the fourth quarter, yielding an insignificant effect for the annual variable. 
of persistence or "inertia" observed in actual inflation. These models therefore have trouble explaining the costs of reducing inflation through tight monetary policy (Ball, 1991; Fuhrer and Moore, 1995).

Do the deviations from rationality that we detect help explain the effects of policy? The answer depends on our choice of a macroeconomic model. In New Classical models based on imperfect information (Lucas, 1972), real output responds positively to surprise movements in inflation. Monetary policy affects output to the extent that it causes such surprises. Our results do not fit easily with this class of models. We find that policy tightenings lead to unexpected increases in inflation for three quarters and do not cause systematic surprises at longer horizons. If output depends only on surprise inflation, then increases in the funds rate should lead to higher output. This is the opposite of the contractionary effects found in this study and many others.

Our results are more consistent with macroeconomic models based on sticky prices and imperfect competition (Romer, 1995, Chapter 6). In these models, firms set prices in advance based on expectations of aggregate demand. An unexpected fall in demand reduces real output even if it does not cause an 
unexpected fall in inflation. Suppose, for example, that demand falls after firms have set prices for the current period. Because price setters cannot respond, there is no initial change in inflation, and hence no inflation surprise. Nonetheless, the decrease in demand at predetermined prices reduces output below the expected level.

In a sticky-price framework, a natural interpretation of our results is that shifts in the fed funds rate affect demand, and agents systematically underestimate this effect. Since increases in the funds rate lead to unexpectedly low demand, they systematically reduce real output. With prices set in advance, the negative surprises are reflected in unexpectedly low output but not unexpectedly low inflation. ${ }^{7}$

\section{B. The Behavior of Expectations}

A large literature from the 1970 s and 1980 s tests the rationality of survey expectations, focusing on expectations of inflation. There is some evidence against rationality, but the results are not conclusive (see Lovell (1986) and Croushore

7 By itself, this story does not explain why policy tightenings lead to unexpectedly high inflation. This result arises, however, if agents underestimate the inflationary effects of the shocks to which policy responds, as well as underestimating the effects of policy. 
(forthcoming)). A recent paper by Keane and Runkle (1990) argues that rationality cannot be rejected in the Survey of professional Forecasters if various problems with previous studies are corrected. Commenting on Keane and Runkle, Bonham and Cohen (1995) present new evidence of irrationality: several macroeconomic variables, including oil prices and unemployment, predict errors in inflation expectations. Keane and Runkle (1995) question the robustness of these results.

Our results contribute to this debate by providing a strong rejection of rationality. Our test is a powerful one because shifts in monetary policy have important effects on output and inflation that must be reflected in expectations for rationality to hold. Our study appears to be the first test of rational expectations to use the federal funds rate as a measure of policy. Previous studies have used money growth, which current researchers view as a less accurate measure of policy. Bonham and Cohen report that money growth does net predict expectational errors. ${ }^{8}$

${ }^{8}$ The Keane-Runkle and Bonham-Cohen papers use panel data on expectations of individual forecasters, whereas we use the mean forecast across individuals. In the earlier studies, micro data are needed for valid tests because different individuals have different information about some variables. In this paper, tests with mean data are valid because we examine the predictive power 
Our results are suggestive about how expectations deviate from rationality. The effects of monetary policy on expected output are dampened relative to the effects on actual output. Perhaps it is common for expectations to underreact to macroeconomic variables, as suggested by Lovell (1961, 1986). Our inflation results suggest that agents are better at understanding the longer-term effects of policy: lags of the funds rate of two years or more have similar effects on expected and actual inflation. Perhaps expectations adjust to a change in circumstances after an initial period of confusion. Future research should explore these ideas.

Future work should also explore the reasons why expectations are not fully rational. One possibility is that agents form expectations using rules of thumb to economize on the costs of gathering and processing information (Ball, 1991). Another is that agents have objectives other than minimizing forecast errors, such as avoiding risks to their reputations as forecasters (Lamont, 1994). Finally, even if agents do minimize

of a variable that is observed by all agents: the change in the fed funds rate. Rationality implies that changes in the funds rate do not forecast the expectational error of any individual. Averaging across individuals, rationality implies that changes in the funds rate do not forecast the mean expectational error. 
forecast errors, shifts in regime could produce rejections of rationality in tests such as ours, which assume a stationary environment (Evans and Wachtel, 1993).

In explaining the behavior of expectations, we must confront the fact that this behavior is consistent across survey respondents ranging from ordinary consumers (the Michigan survey) to professional forecasters (the SPF). The idea that expectations are based on rules of thumb is plausible for consumers but less plausible for professional forecasters, who have strong incentives to optimize fully. Concerns about professional reputation appear relevant for forecasters but not for consumers. And forecasters who follow the economy closely ought to adjust to regime changes more quickly than ordinary citizens. It is not obvious how to explain all of our results at once. 
Table 1

Output Expectations

Survey of Professional Forecasters

1968Q4 to $1992 \mathrm{Q} 4(\mathrm{~N}=97)$
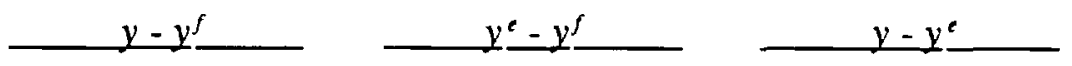

FF1

$-0.815$

$-0.803$

$-0.407$

$-0.401$

$-0.408$

$-0.402$

(0.136)

(0.144)

(0.133)

(0.136)

(0.137)

$(0.136)$

FF2

$-0.161$

$-0.078$

$-0.084$

(0.166)

$(0.151)$

$(0.077)$

$\chi^{2}$ SIG.

$<.01$

$<.01$

$<.01$

$<.01$

$<.01$

0.01

$\bar{R}^{2}$

.45

.46

.17

.17

.19

.19

Notes: This table reports results from regressing the column variable on the $F F$ variable(s) listed in the rows. The regression coefficients are listed, with standard errors in parentheses. $\chi^{2}$ SIG. is the significance level for the test that the coefficients on all the $F F$ variables are zero. 
Table 2

Output Expectations

Livingston Survey

$1971 \mathrm{H} 1$ to $1992 \mathrm{H} 2(\mathrm{~N}=44)$

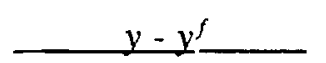

FF1

$F F 2$

$\chi^{2}$ SIG.

$\bar{R}^{2}$ $\begin{array}{ll}-0.706 & -0.707\end{array}$

$(0.134) \quad(0.133)$

$\begin{array}{ll}- & -0.298 \\ - & (0.112)\end{array}$

(0.112)

$<.01<.01$
$.44 \quad .51$

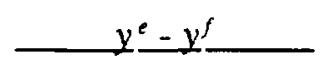

$-0.401$

$(0.129) \quad(0.127)$

$-$

$-0.157$

(0.125)

$<.01<.01$

.13

.16

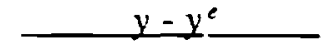

$\begin{array}{ll}-0.304 & -0.305\end{array}$

(0.120) (0.122)

$\begin{array}{cc}- & -0.141 \\ - & (0.070)\end{array}$

$.01 \quad 0.03$

.17

.20

Notes: See notes for Table 1. 
Table 3

Inflation Expectations

Survey of Professional Forecasters

1969Q1 to $1992 \mathrm{Q} 4(\mathrm{~N}=96)$

\begin{tabular}{|c|c|c|c|c|c|c|c|c|c|}
\hline \multirow[b]{2}{*}{$F F 1$} & \multicolumn{3}{|c|}{$\pi-\pi^{f}$} & \multicolumn{3}{|c|}{$\pi^{e}-\pi^{f}$} & \multicolumn{3}{|c|}{$\pi-\pi^{e}$} \\
\hline & $\begin{array}{c}0.173 \\
(0.104)\end{array}$ & $\begin{array}{c}0.197 \\
(0.110)\end{array}$ & $\begin{array}{c}0.123 \\
(0.110)\end{array}$ & $\begin{array}{l}-0.142 \\
(0.070)\end{array}$ & $\begin{array}{l}-0.121 \\
(0.063)\end{array}$ & $\begin{array}{l}-0.150 \\
(0.062)\end{array}$ & $\begin{array}{c}0.315 \\
(0.134)\end{array}$ & $\begin{array}{c}0.318 \\
(0.136)\end{array}$ & $\begin{array}{c}0.273 \\
(0.136)\end{array}$ \\
\hline$F F 2$ & - & $\begin{array}{l}-0.320 \\
(0.115)\end{array}$ & $\begin{array}{l}-0.304 \\
(0.105)\end{array}$ & - & $\begin{array}{l}-0.290 \\
(0.090)\end{array}$ & $\begin{array}{l}-0.284 \\
(0.086)\end{array}$ & - & $\begin{array}{l}-0.030 \\
(0.069)\end{array}$ & $\begin{array}{l}-0.020 \\
(0.063)\end{array}$ \\
\hline$F F 3$ & - & - & $\begin{array}{l}-0.246 \\
(0.115)\end{array}$ & - & - & $\begin{array}{l}-0.097 \\
(0.032)\end{array}$ & - & - & $\begin{array}{l}-0.149 \\
(0.121)\end{array}$ \\
\hline$\chi^{2}$ SIG &. .10 & 0.01 & $<.01$ & .04 & $<.01$ & $<.01$ & .02 & .06 & .04 \\
\hline $\bar{R}^{2}$ & .05 & .22 & .31 & .02 & .29 & .31 & .21 & .20 & .24 \\
\hline
\end{tabular}

Notes: See notes for Table 1. 
Table 4

Inflation Expectations

Livingston Survey

$1958 \mathrm{H} 1$ to $1992 \mathrm{H} 2(\mathrm{~N}=70)$

\begin{tabular}{|c|c|c|c|c|c|c|c|c|c|}
\hline \multirow[b]{2}{*}{$F F 1$} & \multicolumn{3}{|c|}{$\pi-\pi^{f}$} & \multicolumn{3}{|c|}{$\pi^{e}-\pi^{f}$} & \multicolumn{3}{|c|}{$\pi-\pi^{2}$} \\
\hline & $\begin{array}{c}0.094 \\
(0.169)\end{array}$ & $\begin{array}{c}0.084 \\
(0.176)\end{array}$ & $\begin{array}{c}0.005 \\
(0.164)\end{array}$ & $\begin{array}{l}-0.250 \\
(0.119)\end{array}$ & $\begin{array}{l}-0.260 \\
(0.100)\end{array}$ & $\begin{array}{l}-0.320 \\
(0.075)\end{array}$ & $\begin{array}{c}0.344 \\
(0.164)\end{array}$ & $\begin{array}{c}0.344 \\
(0.164)\end{array}$ & $\begin{array}{c}0.325 \\
(0.170)\end{array}$ \\
\hline$F F 2$ & - & $\begin{array}{l}-0.365 \\
(0.102)\end{array}$ & $\begin{array}{l}-0.383 \\
(0.096)\end{array}$ & - & $\begin{array}{l}-0.373 \\
(0.090)\end{array}$ & $\begin{array}{l}-0.386 \\
(0.086)\end{array}$ & - & $\begin{array}{c}0.007 \\
(0.078)\end{array}$ & $\begin{array}{c}0.003 \\
(0.081)\end{array}$ \\
\hline$F F 3$ & - & - & $\begin{array}{l}-0.307 \\
(0.153)\end{array}$ & - & - & $\begin{array}{l}-0.232 \\
(0.072)\end{array}$ & - & - & $\begin{array}{l}-0.075 \\
(0.148)\end{array}$ \\
\hline$\chi^{2}$ SIG. & .58 & $<.01$ & $<.01$ & .04 & $<.01$ & $<.01$ & .04 & .11 & .16 \\
\hline $\bar{R}^{2}$ & .01 & .15 & .24 & -.03 & .29 & .41 & .08 & .06 & .06 \\
\hline
\end{tabular}

Notes: See notes for Table 1. 
Table 5

Inflation Expectations

Michigan Survey

1969Q1 to $1992 \mathrm{Q} 4(\mathrm{~N}=96)$

\begin{tabular}{|c|c|c|c|c|c|c|c|c|c|}
\hline \multirow[b]{2}{*}{$F F 1$} & \multicolumn{3}{|c|}{$\pi-\pi^{f}$} & \multicolumn{3}{|c|}{$\pi^{e}-\pi^{f}$} & \multicolumn{3}{|c|}{$\pi-\pi^{e}$} \\
\hline & $\begin{array}{c}0.133 \\
(0.159)\end{array}$ & $\begin{array}{c}0.168 \\
(0.148)\end{array}$ & $\begin{array}{c}0.076 \\
(0.148)\end{array}$ & $\begin{array}{l}-0.163 \\
(0.106)\end{array}$ & $\begin{array}{l}-0.137 \\
(0.085)\end{array}$ & $\begin{array}{l}-0.220 \\
(0.070)\end{array}$ & $\begin{array}{c}0.296 \\
(0.098)\end{array}$ & $\begin{array}{c}0.304 \\
(0.101)\end{array}$ & $\begin{array}{c}0.296 \\
(0.112)\end{array}$ \\
\hline$F F 2$ & - & $\begin{array}{l}-0.469 \\
(0.120)\end{array}$ & $\begin{array}{l}-0.450 \\
(0.107)\end{array}$ & - & $\begin{array}{l}-0.352 \\
(0.084)\end{array}$ & $\begin{array}{l}-0.334 \\
(0.065)\end{array}$ & - & $\begin{array}{l}-0.117 \\
(0.080)\end{array}$ & $\begin{array}{c}-0.116 \\
(0.078)\end{array}$ \\
\hline$F F 3$ & - & - & $\begin{array}{l}-0.305 \\
(0.160)\end{array}$ & - & - & $\begin{array}{c}-0.277 \\
(0.072)\end{array}$ & - & - & $\begin{array}{l}-0.027 \\
(0.120)\end{array}$ \\
\hline$\chi^{2}$ SIG. & .40 & $<.01$ & $<.01$ & .13 & $<.01$ & $<.01$ & $<.01$ & $<.01$ & .01 \\
\hline $\bar{R}^{2}$ & .02 & .24 & .32 & .05 & .27 & .40 & .18 & .20 & .19 \\
\hline
\end{tabular}

Notes: See notes for Table 1. 
Table 6

Inflation Expectations

Survey of Professional Forecasters

1969Q1 to 1992Q4 $(\mathrm{N}=96)$

\begin{tabular}{|c|c|c|c|}
\hline & $\pi-\pi^{f}$ & $\pi^{e}-\pi^{f}$ & $\pi-\pi^{e}$ \\
\hline$\Delta f f_{-1}$ & $\begin{array}{c}0.424 \\
(0.245)\end{array}$ & $\begin{array}{c}0.124 \\
(0.147)\end{array}$ & $\begin{array}{c}0.300 \\
(0.200)\end{array}$ \\
\hline$\Delta f f_{.2}$ & $\begin{array}{c}0.046 \\
(0.137)\end{array}$ & $\begin{array}{l}-0.149 \\
(0.066)\end{array}$ & $\begin{array}{c}0.194 \\
(0.139)\end{array}$ \\
\hline$\Delta f f_{-3}$ & $\begin{array}{c}0.148 \\
(0.121)\end{array}$ & $\begin{array}{l}-0.240 \\
(0.120)\end{array}$ & $\begin{array}{c}0.388 \\
(0.180)\end{array}$ \\
\hline$\Delta f f_{-4}$ & $\begin{array}{l}-0.139 \\
(0.142)\end{array}$ & $\begin{array}{l}-0.328 \\
(0.068)\end{array}$ & $\begin{array}{c}0.189 \\
(0.153)\end{array}$ \\
\hline$\Delta f f_{-s}$ & $\begin{array}{l}-0.190 \\
(0.099)\end{array}$ & $\begin{array}{l}-0.341 \\
(0.083)\end{array}$ & $\begin{array}{c}0.151 \\
(0.089)\end{array}$ \\
\hline$\Delta f f_{-6}$ & $\begin{array}{l}-0.256 \\
(0.164)\end{array}$ & $\begin{array}{l}-0.239 \\
(0.124)\end{array}$ & $\begin{array}{l}-0.017 \\
(0.082)\end{array}$ \\
\hline$\Delta f f_{-7}$ & $\begin{array}{l}-0.318 \\
(0.135)\end{array}$ & $\begin{array}{l}-0.239 \\
(0.095)\end{array}$ & $\begin{array}{l}-0.079 \\
(0.106)\end{array}$ \\
\hline$\Delta f f_{-8}$ & $\begin{array}{l}-0.396 \\
(0.157)\end{array}$ & $\begin{array}{l}-0.263 \\
(0.072)\end{array}$ & $\begin{array}{l}-0.133 \\
(0.137)\end{array}$ \\
\hline$\Delta f f_{-9}$ & $\begin{array}{l}-0.293 \\
(0.152)\end{array}$ & $\begin{array}{l}-0.172 \\
(0.074)\end{array}$ & $\begin{array}{l}-0.121 \\
(0.140)\end{array}$ \\
\hline$\Delta f f_{-10}$ & $\begin{array}{l}-0.315 \\
(0.121)\end{array}$ & $\begin{array}{l}-0.170 \\
(0.077)\end{array}$ & $\begin{array}{l}-0.145 \\
(0.149)\end{array}$ \\
\hline$\Delta f f_{-11}$ & $\begin{array}{l}-0.113 \\
(0.141)\end{array}$ & $\begin{array}{l}-0.015 \\
(0.052)\end{array}$ & $\begin{array}{l}-0.099 \\
(0.143)\end{array}$ \\
\hline$\Delta f f_{-12}$ & $\begin{array}{l}-0.267 \\
(0.141)\end{array}$ & $\begin{array}{l}-0.056 \\
(0.079)\end{array}$ & $\begin{array}{l}-0.211 \\
(0.144)\end{array}$ \\
\hline$\chi^{2}$ SIG. & .02 & $<.01$ & .37 \\
\hline $\bar{R}^{2}$ & .33 & .37 & .19 \\
\hline
\end{tabular}

Notes: See notes for Table 1 ; $\Delta f_{-I}$ is the change in the federal funds rate between quarter $t-I$ and quarter $t-I-1$. 
Figure 1

OUTPUT FORECAST ERRORS AND MONETARY POLICY

SURVEY OF PROFESSIONAL FORECASTERS 6804 TO 9204

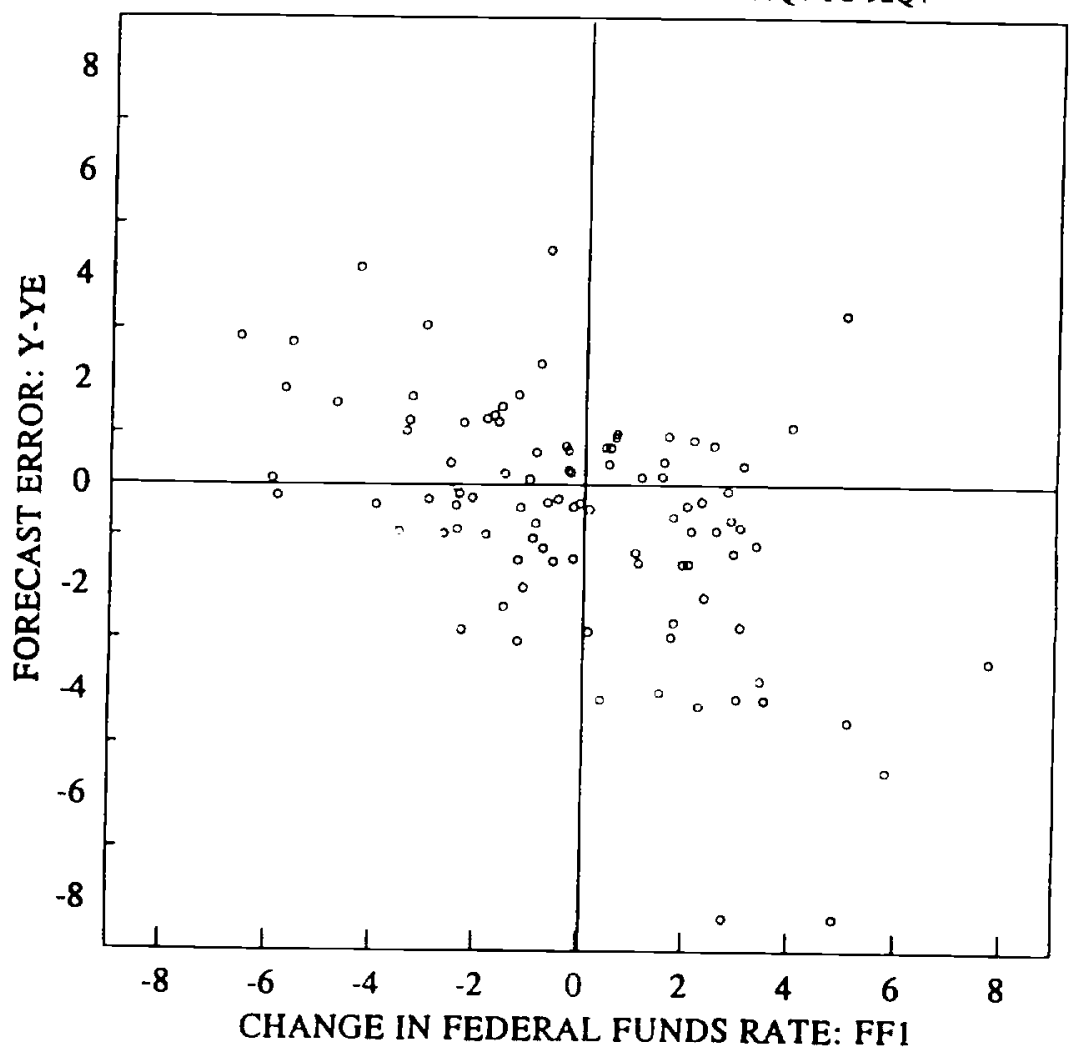

OUTPUT FORECAST ERRORS AND MONETARY POLICY LIVINGSTON SURVEY 71H1 TO 92H2

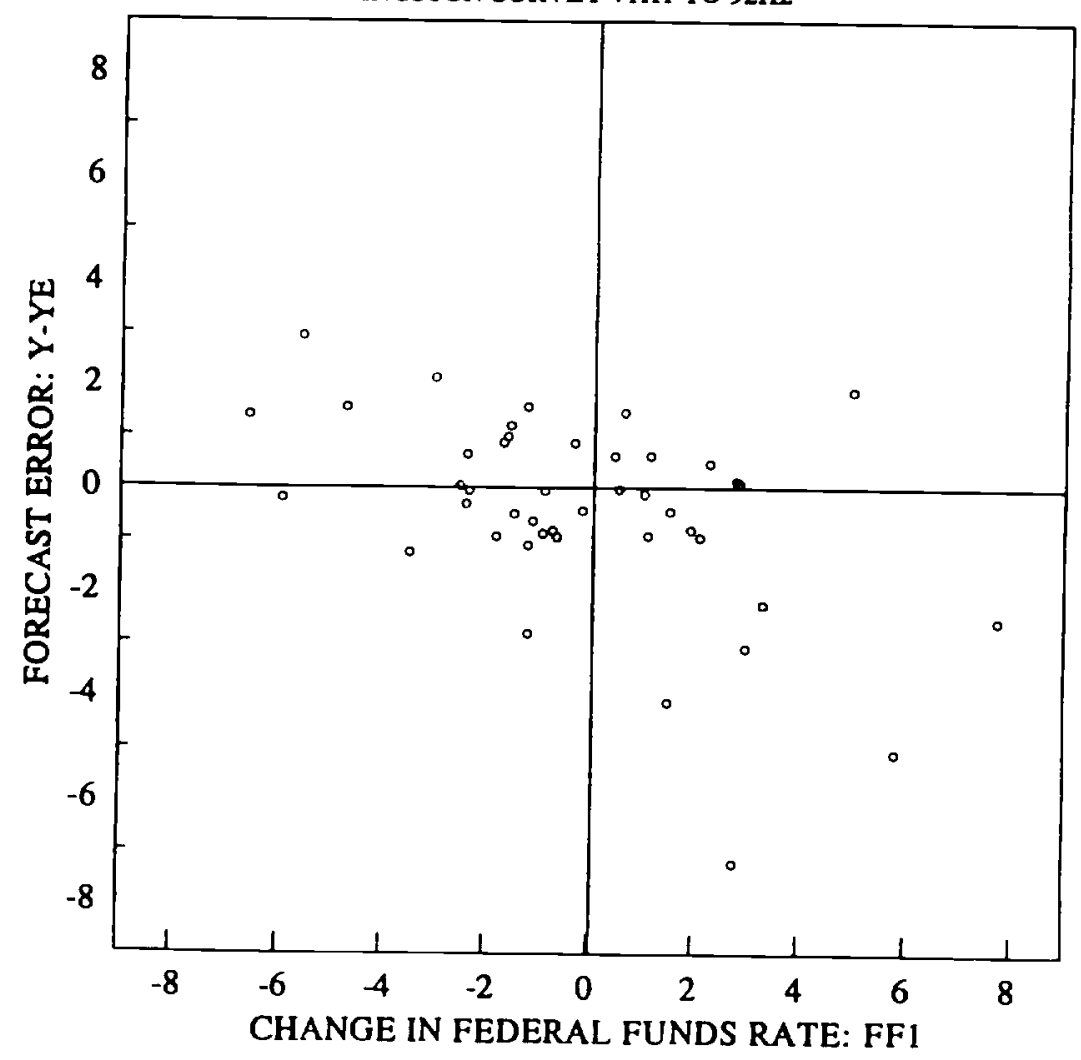




\section{DATA APPENDIX}

This appendix describes the data used in the paper in full detail.

\section{Survey of Professional Forecasters}

The Survey of Professional Forecasters was begun in 1968 by Victor Zarnowitz and was run by the American Statistical Association and the National Bureau of Economic Research. They stopped doing the survey in 1990, at which time it was taken over by the Federal Reserve Bank of Philadelphia. It is the longestrunning quarterly survey of forecasts in the United states. The survey is taken in the middle of the quarter, when forecasters have relatively little information about the current quarter.

The forecasts for output growth used in this paper are calculated by comparing the mean forecast for the level of real GNP (GDP beginning in 1992) four quarters ahead to the forecast for the level of real GNP in the current quarter. The growth rate calculated from these two forecasts is compared to the actual growth rate of real GNP. The actual growth rate is calculated from the data available three months after the end of each quarter. This enables us to avoid issues associated with rebenchmarking of data and changing of base years.

The forecasts of inflation are constructed from forecasts of 
the GDP deflator four quarters ahead and in the current quarter. As with output, the actual inflation data are the data available three months after the end of a quarter.

To calculate the $y^{f}$ and $\Pi^{f}$ variables, we estimate time-series models for quarterly values of actual $y$ and $\pi$. For $y^{f}$, we estimate a random walk model with drift and a change in drift in 1973Q2. We run a series of rolling regressions with data beginning in 1961Q1. Similarly, the $\Pi^{f}$ variable is created from rolling regressions with data beginning in 194703 . We assume an IMA $(1,1)$ model for quarterly inflation.

\section{Michigan Survey of Consumers}

The University of Michigan Survey Research Center began doing quarterly surveys of inflation on a regular basis in 1969. They ask the question: "By what percent do you expect prices to go up, on average, during the next 12 months?" Prior to 197703, the responses were categorical (for example, prices will rise 2 to 4 percent). For this period, we use Juster and Comment's (1980) method to translate the categorical responses into a mean forecast. From 1969 to 1977 the survey was quarterly, in the second month of each quarter; after that it was monthly, so we use the forecasts from the second month of each quarter to be consistent with the earlier data. Since the question about 
inflation is asked of consumers, we use the CPI as our measure of actual inflation. For an observation in quarter $t$, inflation is the change in the CPI from the second month of quarter to the second month of quarter $t+4$ (using data available three months after the end of each quarter). We create the $\Pi^{f}$ variable using the same procedure as for the SPF case.

\section{Livingston Survey}

The Livingston Survey was begun in December 1946 by Joseph Livingston, a newspaper columnist in Philadelphia. Forecasts by economists are collected each June and December for a variety of macroeconomic variables. CPI inflation forecasts were collected since the survey began, but real GNP forecasts were not collected until $1971 \mathrm{HI}$.

Unlike the SPF, the Livingston Survey did not (until 1992) ask for forecasts for the current period. For example, the June survey asks people to forecast the level of the CPI in June of the following year but does not ask for a forecast for June of the current year. At the time the survey is collected, most forecasters have only the April CPI data, though some may have the May data. Following Carlson (1977), we assume that all forecasters have the April CPI data (for the June survey) or October CPI data (for the December survey) when they make their 
forecasts. This means that the inflation forecasts are really 14 months rather than 12 months ahead. Similarly, the forecasts for real GNP, which is a quarterly variable, are five quarters rather than four quarters ahead.

We match this timing by measuring actual inflation over 14 months and actual output growth over five quarters. (The data are expressed as annual growth rates.) otherwise, the procedures we follow for the Livingston Survey are parallel to those for the SPF and Michigan surveys. For the time-series forecasts of output and inflation, the rolling regressions use quarterly data beginning in 194702 . 


\section{REFERENCES}

Ball, Laurence. "The Genesis of Inflation and the Costs of Disinflation," Journal of Money, Credit and Banking 23 (August 1991, part 2), pp. 439-52.

Ball, Laurence, and Stephen Cecchetti. "Inflation and Uncertainty at Short and Long Horizons," Brookings Papers on Economic Activity (1990:1), pp. 215-54.

Barsky, Robert B. "The Fisher Hypothesis and the Forecastability and Persistence of Inflation," Journal of Monetary Economics 19 (January 1987), pp. 3-24.

Bernanke, Ben S., and Alan S. Blinder, "The Federal Funds Rate and the Channels of Monetary Transmission," American Economic Review 82 (September 1992), pp. 901-21.

Beveridge, Stephen, and Charles Nelson. "A New Approach to Decomposition of Economic Time Series into Permanent and Transitory Components with Particular Attention to Measurement of the 'Business Cycle'," Journal of Monetary Economics 7 (March 1981), pp. 151-74.

Bonham, Carl, and Richard Cohen. "Testing the Rationality of Price Forecasts: Comment," American Economic Review 85 (March 1995), pp. $284-9$.

Campbel1, John Y., and N. Gregory Mankiw. "Are Output 
Fluctuations Transitory?" Quarterly Journal of Economics 102

(November 1987), pp. 857-80.

Carlson, John A. "A Study of Price Forecasts," Annals of

Economic and Social Measurement 6 (Winter 1977), pp. 27-56.

Christiano, Lawrence J., and Martin Eichenbaum. "Liquidity

Effects and the Monetary Transmission Mechanism, "American

Economic Review 82 (May 1992), pp. 346-353.

Croushore, Dean. "Introducing: The Survey of Professional

Forecasters," Federal Reserve Bank of Philadelphia Business

Review, November/December 1993, pp. 3-15.

Croushore, Dean. "Inflation Forecasts: How Good Are They?"

Federal Reserve Bank of Philadelphia Business Review, forthcoming.

Evans, Martin, and Paul Wachtel. "Inflation Regimes and the Sources of Inflation Uncertainty," Journal of Money, Credit, and Banking 25 (August 1993, part 2), pp. 475-511.

Fuhrer, Jeffrey C., and George R. Moore. "Inflation Persistence," Quarterly Journal of Economics 110 (February 1995), pp. 127159.

Juster, F. Thomas, and Robert Comment. "A Note on the Measurement of Price Expectations," Institute for Social Research working paper, University of Michigan (1980). 
Keane, Michael P., and David E. Runkle. "Testing the Rationality of Price Forecasts: New Evidence from Panel Data," American Economic Review 80 (September 1990), pp. 714-35.

Keane, Michael P., and David E. Runkle. "Testing the Rationality of Price Forecasts: Reply," American Economic Review 85 (March 1995), p. 290.

Lamont, Owen. "Macroeconomic Forecasts and Macroeconomic Forecasters," manuscript, University of Chicago (1994). Lovell, Michael C., "Manufacturers' Inventories, Sales Expectations, and the Accelerator Principle," Econometrica 29 (July 1961), pp. 293-314. , "Tests of the Rational Expectations Hypothesis," American Economic Review 76 (March 1986), pp. 110-24. Lucas, Robert E., Jr. "Expectations and the Neutrality of Money," Journal of Economic Theory 4 (April 1972), pp. 103-24. Newey, Whitney K., and Kenneth D. West. "A Simple, Positive Semi-Definite, Heteroskedasticity and Autocorrelation Consistent Covariance Matrix," Econometrica 55 (May 1987), pp. $703-8$

Noble, Nicholas R., and T. Windsor Fields. "Testing the Rationality of Inflation Expectations Derived from Survey Data: A Structure-Based Approach," Southern Economic Journal 
49 (October 1982), pp. 361-73.

Perron, Pierre. "The Great Crash, the Oil Price Shock, and the

Unit Root Hypothesis," Econometrica 57 (November 1989), pp. $1361-1401$

Romer, David, Advanced Macroeconomics, University of California at Berkeley, 1995.

Taylor, John B., "Staggered Wage Setting in a Macro Model," American Economic Review 69 (May 1979), pp. 108-113.

Taylor, Herb. "The Livingston Surveys: A History of Hopes and Fears," Federal Reserve Bank of Philadelphia Business Review (January/February 1992), pp. 15-27. 